Overview of mental

health issues of

COVID-19: need of

the hour

Barikar Chandrappa Malathesh (D) ,' Seshadri Sekhar Chatterjee (D) ,2 Soumitra Das ${ }^{3}$

\section{To the Editor,}

First detected in Wuhan, China, severe acute respiratory syndrome coronavirus 2 (SARS CoV 2) virus is creating havoc worldwide and having an unprecedented impact on public health and society, so much so that it was declared a 'Public Health Emergency of International Concern' in January 2020 and further as a 'pandemic' in March 2020. So far, it has affected more than 1.7 million people all over the world, causing 110 thousand deaths across 195 countries. $^{1}$

At present, different countries are in different stages of this viral transmission ranging from imported cases only to community transmission. So, in this regard, WHO has come out with strategies like promoting personal hygiene, social distancing, isolation of confirmed cases and quarantine of suspected cases. ${ }^{2}$ Adding on to that, each country has imposed legal and policy measures like lockdown of cities and imposing curfew, banning all modes transport, shutting down all non-essential services and so on. Despite the above measures, many developed countries have not been able to contain the coronavirus disease of 2019 (covid-19) and ensure adequate medical care to the affected. ${ }^{3}$

Furthermore, there is rapid, uncontrolled spread of false and unreliable information on social media about the covid-19 pandemic, which

\footnotetext{
${ }^{1}$ Department of Psychiatry, National Institute of Mental Health and Neuro Sciences, Bangalore, India

${ }^{2}$ Department of Psychiatry, West Bengal University of Health Sciences, Kolkata, India

${ }^{3}$ NorthWestern Mental Health, Parkville, Victoria, Australia
}

Correspondence to Dr Barikar Chandrappa

Malathesh; bc.malathesh@gmail.com has been termed as an 'infodemic', resulting in significant apprehension and uncertainty among the community. This may put the community at risk and push the public into confusion, anxiety and panic about their health risks related to covid-19. ${ }^{45}$

Along with social, legal and policy measures about covid-19, mental health issues are also of paramount importance to the community. In this regard, the government should take the community into confidence by the effective handling of such pandemic, which can be done by providing authentic information and addressing this infodemic. The authentic information provided should be accessible and understandable in language that is appropriate for the community through appropriate media. Government should address the pandemicrelated frequently asked questions by making a document of 'Frequently asked Questions and Answers' available in appropriate medias like written, audio and video format and ensuring that it is accessible to all including those having different forms of disability.

Infodemic may cause confusion, anxiety and panic about the health risks in the community. Such attempts of spreading unreliable information should be taken seriously and should be dealt with under laws like Cyber Law and Epidemic Act of India. Infodemic-related psychological distress is common and this should be handled by providing a helpline number and if further necessary appropriate counselling. The government can also provide official helpline numbers or official website addresses to the general public to receive authentic information. The public should be advised to avoid searching for information related to SARS CoV2/covid-19 from unreliable sources. $^{5}$

Many countries have imposed home and hospital quarantine to address the covid-19 pandemic. 'Quarantine' curtails the freedom of the individual to a certain extent for the larger interests of the public. The longer the quarantine period is, the greater is the psychological, emotional and financial stress due to loss of personal freedom, new daily routine, lack of social togetherness and financial difficulties. Quarantine may also lead to difficulty in accessing mental healthcare services, especially in those with a pre-existing psychiatric disorder. The above factors act individually or together leading to an increase in new-onset anxiety and stress related disorders and worsening of preexisting psychiatric disorders. ${ }^{6-8}$ We suggest promoting Tele-Psychiatry to address the issue of difficulty in accessing mental healthcare services, for those with pre-existing psychiatric disorder, thereby ensuring continued care. Governments should also relax the norms for teleconsultation in this crisis situation. Other suggestions to the individuals affected would be to enhance virtual social contacts during this time of being quarantined and find psychological support from family and friends through virtual modes of communication like audio/ video-based conversations, but at the same time they should reduce discussions about SARS CoV2/covid-19 as it might lead to further spread of misinformation and increase in stress levels. Quarantined persons can also get involved in some form of indoor physical activity/meditation/yoga to keep themselves healthy. ${ }^{9}$

The flu-like symptoms that occur in covid-19 can also be caused by other corona group viruses and noncorona group viruses and those may be self-limiting. Any flu-like symptoms is likely to increase health-related anxiety and make an individual worry if they have become a victim of covid19 , so hospitals should include mental health screeners for people coming with influenza like symptoms so that those needing psychological help can be identified as early as possible. ${ }^{10}$

In summary, the pandemic threat of covid-19 is real and expected to be long-lasting. This pandemic will bring forth a multitude of psychiatric morbidities, thereby demanding increased mental health service delivery. Governments should come out with policies to ensure that the increased demands for psychiatric services are adequately met. There is 
also a need to ensure that 'infodemic' does not become more burdensome than the pandemic itself.

\section{Twitter Seshadri Sekhar Chatterjee @SeshadriSSC}

Contributors SD provided the basic idea of the correspondence. BCM performed the literature search and SSC provided critical revision for the manuscript. All the authors contributed to and approved the final manuscript.

Funding The authors have not declared a specific grant for this research from any funding agency in the public, commercial or not-for-profit sectors.

Competing interests None declared.

Patient consent for publication Not required.

Provenance and peer review Not commissioned; externally peer reviewed.

\section{(2) OPEN ACCESS}

Open access This is an open access article distributed in accordance with the Creative Commons Attribution Non Commercial (CC BY-NC 4.0) license, which permits others to distribute, remix, adapt, build upon this work non-commercially, and license their derivative works on different terms, provided the original work is properly cited, appropriate credit is given, any changes made indicated, and the use is non-commercial. See: http://creativecommons.org/licenses/by-nc/4.0/.
(C) Author(s) (or their employer(s)) 2020. Re-use permitted under CC BY-NC. No commercial re-use. See rights and permissions. Published by BMJ.

\section{(A) Check for updates}

To cite Malathesh BC, Chatterjee SS, Das S. General Psychiatry Epub ahead of print: [please include Day Month Year]. doi:10.1136/gpsych-2020-100233

Received 31 March 2020

Revised 23 April 2020

Accepted 25 April 2020

General Psychiatry 2020;33:e100233.

doi:10.1136/gpsych-2020-100233

ORCID iDs

Barikar Chandrappa Malathesh http://orcid.org/ 0000-0001-9107-1717

Seshadri Sekhar Chatterjee http://orcid.org/ 0000-0002-5554-2216

\section{REFERENCES}

1 WHO. WHO. [Online]; [cited 2020 Apr 14], 2020. Available: https://www.who.int/docs/ default-source/coronaviruse/situationreports/20200413-sitrep-84-covid-19.pdf? sfvrsn=44f511ab 2

2 WHO. World Health Organisation. [Online]; [cited 2020 Mar 24], 2020. Available: https://www.who.int/emergencies/diseases/ novel-coronavirus-2019/advice-for-public

3 Horowitz J, Bubola E, Povoledo E. The New York Times. [Online]; [cited 2020 Mar 24],
2020. Available: https://www.nytimes.com/ 2020/03/21/world/europe/italy-coronaviruscenter-lessons.html

4 Delcker J, Wanat Z, Scott M. POLITICO.

[Online]; [cited 2020 Mar 24], 2020.

Available: https://www.politico.com/ news/2020/03/16/coronavirus-fake-newspandemic-133447

5 WHO. WHO. [Online]; [cited 202003 14], 2018. Available: https://www.who. int/emergencies/diseases/managingepidemics-interactive.pdf?ua $=1$

6 Hawryluck L, Gold WL, Robinson S, et al. SARS control and psychological effects of quarantine, Toronto, Canada. Emerg Infect Dis 2004;10:1206-12.

7 Ko C-H, Yen C-F, Yen J-Y, et al. Psychosocial impact among the public of the severe acute respiratory syndrome epidemic in Taiwan. Psychiatry Clin Neurosci 2006;60:397-403.

8 Köhler-Forsberg O, Petersen L, Gasse C, et al. A nationwide study in Denmark of the association between treated infections and the subsequent risk of treated mental disorders in children and adolescents. JAMA Psychiatry 2019;76:271-9.

9 Mitchell A. QNS. [Online]; [cited 2020 Mar 24], 2020. Available: https://qns.com/story/ 2020/03/20/here-are-10-things-to-dowhile-in-quarantine-this-weekend/

10 Zhang J, Wu W, Zhao X, et al. Recommended psychological crisis intervention response to the 2019 novel coronavirus pneumonia outbreak in China: a model of West China Hospital. Precis Clin Med 2020;3:3-8.

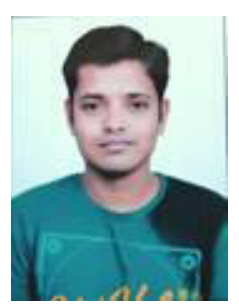

Dr Malathesh obtained a bachelor's degree in medicine from JJM Medical College, Davangere, India, and a Master's degree in Psychiatry from BJ Medical College, Pune, India. He further obtained a fellowship in Forensic Psychiatry from the National Institute of Mental Health and Neuro Sciences, Bengaluru. He currently is a Senior Resident Doctor of Psychiatry at NIMHANS (Banglore, India) and he is working at India's premier institute in mental health, the National Institute of Mental Health and Neuro Sciences, as a resident doctor in the Department of Tele Medicine. His main research interests include Forensic Psychiatry and General Adult Psychiatry. 